\title{
Effect of zinc and iron on growth, flowering and shelf life of marigold under the agro-climatic conditions of Sawabi
}

\author{
Altaf Hussain ${ }^{1}$, Ghulam Nabi ${ }^{1}$, Muhammad Ilyas ${ }^{1 *}$, Muhammad Noman \\ $\mathrm{Khan}^{1}$, Waqas Khan ${ }^{1}$, Shah Zeb ${ }^{2}$, Muhammad Hilal ${ }^{1}$, Yasir Ali ${ }^{1}$ and \\ Abdullah Khan ${ }^{1}$ \\ 1. Department of Horticulture, The University of Agriculture Peshawar-Pakistan \\ 2. Department of Horticulture, Agriculture Research Institute Tarnab, Peshawar-Palistan \\ *Corresponding author's email: muhammadalyas12322@gmail.com \\ Citation \\ Altaf Hussain, Ghulam Nabi, Muhammad Ilyas, Muhammad Noman Khan, Waqas Khan, Shah Zeb, Muhammad \\ Hilal, Yasir Ali and Abdullah Khan . Effect of zinc and iron on growth, flowering and shelf life of marigold under \\ the agro-climatic conditions of Sawabi. Pure and Applied Biology. Vol. 9, Issue 1, pp180-192. \\ http://dx.doi.org/10.19045/bspab.2020.90022
}

\begin{tabular}{llll}
\hline \hline Received: 13/06/2019 & Revised: 24/08/2019 & Accepted: 16/09/2019 & Online First: 04/10/2019 \\
\hline \hline
\end{tabular}

\section{Abstract}

A field experiment on the "Effect of zinc and iron on growth, flowering and shelf life of marigold" was carried out at Agricultural Research Station Swabi during 2018 to determine the optimum level of zinc and Iron on growth, flowering and shelf life of marigold flower, for the purpose to fulfill the demand of cut and loose flowers in local market. The experiment was laid out in Randomized Complete Block Design (RCBD) having three replications. Two factors were used in the experiment i.e. Four levels of zinc $(0,0.2,0.4$ and $0.6 \%)$. And three levels of iron $(0,0.3$ and $0.6 \%)$. Zinc sulphate and iron sulphate were used as source for zinc and iron application. The results of the experiment showed that the maximum number of branches plant ${ }^{-1}(17.33)$, number of flowers plant ${ }^{-1}(10.11)$, flower diameter $(9.10$ $\mathrm{cm}$ ), fresh flower weight $(17.51 \mathrm{~g})$, dry flower weight $(3.06 \mathrm{~g})$, shelf life (5.22 days) and minimum days to flowering (16.67 days) was observed on $0.6 \%$ application of zinc as a foliar spray. Maximum plant height $(49.04 \mathrm{~cm})$ and stem diameter $(1.12 \mathrm{~cm})$ was noted on $0.4 \%$ of zinc foliar application. In case of iron maximum number of branches plant ${ }^{-1}$ (18.58), numbers of flowers plant ${ }^{-1}$ (10.79), flower diameter $(9.48 \mathrm{~cm})$, fresh flower weight $(19.36 \mathrm{~g})$, dry flower weight $(3.40 \mathrm{~g})$, shelf life (5.67 days) and minimum days to flowering (15.42 days) was recorded on $0.6 \%$ application of iron. Maximum plant height $(51.22 \mathrm{~cm})$ and stem diameter $(1.19 \mathrm{~cm})$ was observed on $0.3 \%$ of iron foliar application. From the results of the experiment it has been concluded that the application of zinc and iron at the rate of $0.6 \%$ gave maximum growth and better quality flowers of marigold in district Swabi and hence recommended for the agro climatic condition of Swabi.

Keywords: Flowering; Growth; Iron; Marigold; Shelf life; Zinc

\section{Introduction}

Marigold (Tagetes erecta L.) is a beautiful commercial flower of Asteraceae family. The genus of annual and perennial plants which belongs to sunflower family (Asteraceae or
Compositeae) is Tagetes. Its genus was designated by Linnaeus in 1753 . The genus of marigold is originated from South and North America. But some genus is adopted throughout the world. The market value and 
demand of marigold in the subcontinent is very high due to its high range of adaptation. In some areas of the world some species of marigold such as Tagetes minuta is known to be toxic and harmful [1].

The height of Tagetes family ranges from 0.1 to $2.2 \mathrm{~m}$. The leaves of most species are green and pinnate. The natural colors of bloom marigold flowers are orange, yellow, golden, white and having maroon color highlights. The floral head diameter of marigold flower ranges from 4 to $6 \mathrm{~cm}$, usually with both disc florets and ray florets. The most popular species of marigold which are grown such as Tagete spatula L. and Tagetes erecta L. are originated from South Africa and Mexico correspondingly. Tagetes erecta L.is generally famous as African marigold, while T. patula as French marigold. Although the origin of African marigold $T$. erecta is Mexico, it is presumed to be of Indian origin, due to its adaptability, popularity and wide cultivation in India. Marigold is generally popular because of its easy cultivation, the adaptability to varying soil and climatic conditions, long flowering duration, wide range of attractive colors and good keeping quality of flowers. Due to these reasons, marigold is used as cut flower and in garden displays, garlands, bouquets and stage decorations [2].

The African marigold (Tagetes erecta L.) produced flowers having orange or yellow color and having big size of flowers [3]. The demand of the cut flowers is very high because of the beautification and attraction of the flower [4]. Due to modern technology new colors have been presented in the cultivars of cut flower as a result of which the market value and demand of the marigold flowers improved [5].

There is a plenty possibility to improve the production of Marigold by implementing appropriate crop managing methods. In order to achieve good quality and maximum production of marigold flowers, we have to improve production and to reduce the physical and biological diseases, submission of main and micronutrients are unavoidable. Now-a-days, micronutrients particularly zinc and irons are slowly achievement impetus amongst the flower cultivators for the reason that, their useful nutritious maintenance and to confirm healthier yield and revenues. Best responses of African marigold for small quantities of micronutrients have been demonstrated by [6]. An appropriate micronutrient amount, period and technique of application will positively increase the productivity and flowers quality [7].

Zinc is an important micro nutrient for plant and plays a vital role in various processes in plants. Zinc is helpful for the production of proteins in plants and a major constituent of ribosomes and important for its development. Zinc is an active nutrient in various biological and chemical processes and has interaction with other elements due to which the uptake of other elements increased. The production of auxin also related with zinc which plays a vital role in plant growth [8]. Zinc is also involved in the production of carbohydrates, absorption of phosphorus and production of RNA. It has noted that zinc is an essential factor of various enzymes and is an important element for the growth and development of plant. Zinc is also known as an important constituent for many growth promoting substances such as for the synthesis of tryptophan and a precursor of indole acetic acid. It has been reported that the essential oil percentage, oil yield and flowers yield of chamomile was increased with the application of zinc [9].

Iron is also important micro nutrients which plays an important role in the respiration and photosynthesis and also affects its properties. Studies showed that iron is an important nutrient for the growth of plant tissues [10]. The shortage of iron can cause several physiological abnormalities such as chlorosis, scorching and resetting etc. [11]. 
Iron is also related with the establishment of chlorophyll. Iron has also a key character in the activation of several enzymes [12]. The studies showed that the application of iron and zinc play a role in the physiological growth the flowers and reduced the amount of ethylene and abscisic acid and as a result of which the shelf life and visual attraction of the flowers increased [13].

Keeping in view the importance of zinc and iron an experiment was conducted to determine the impact of zinc and iron on growth, flowering and shelf life of marigold flowers in the conditions of district Swabi having the objectives to determine the optimum level of zinc on growth, flowering and shelf life of marigold flower and to investigate the optimum level of Iron on growth, flowering and shelf life of marigold flower.

\section{Materials and methods}

An experiment "Effect of zinc and iron on growth, flowering and shelf life of marigold" was carried out at Agricultural Research Station Swabi, during 2018. The research was aimed to find out the growth, flowering and shelf life of marigold flowers. The research was arranged in Randomized Complete Block Design (RCBD). Total treatments were 12 and all treatments were replicated three times i.e., control, zinc, iron and their interaction (Table 1).

Table 1. Distribution of factors, treatments and their levels

\begin{tabular}{|l|l|}
\hline Factor A (Iron) & Factor B (Zinc) \\
\hline $\mathrm{I}_{1}=$ Control $(0)$ & $\mathrm{Z}_{1}=$ Control $(0)$ \\
\hline $\mathrm{I}_{2}=0.3 \%$ & $\mathrm{Z}_{2}=0.2 \%$ \\
\hline $\mathrm{I}_{3}=0.6 \%$ & $\mathrm{Z}_{3}=0.4 \%$ \\
\hline & $\mathrm{Z}_{4}=0.6 \%$ \\
\hline
\end{tabular}

\section{Preparation of field}

Before sowing of plants, field was ploughed thoroughly and leveled. Field was cultivated with the help of mechanical Cultivator. Soil was fine graded and pulverized. All cultural practices i.e., irrigation, weeding and crop protection was adopted according to the need till the trial end.

\section{Planting materials}

Hybrid variety (Inca 2 yellow) Tagetes erecta was selected. Seedlings were taken from Agriculture research station swabi. Seedlings were transplanted to plot in the mid of September 2018, when reached to 4-5 leaves stage with $40 \times 30 \mathrm{~cm}$ plant spacing. Zinc and iron was applied before emergence of flower buds. Zinc sulphate and iron sulphate was taken as source for foliar application of zinc and iron.

\section{Study parameters}

The subsequent parameters were recorded. Plant height (cm)
Data on plant height were recorded with the help of measuring tape from the base of plant to top of plant. From each treatment plants were selected randomly in each replication and mean data was noted.

\section{Number of branches plant ${ }^{1}$}

The data on numbers of branches were calculated by calculating the amount of branches of every treatment in all of the replication. For this purpose five plants were randomly selected in all treatment and in every replication and their number of branches plant ${ }^{-1}$ was counted and then their mean was calculated.

Stem diameter $(\mathbf{c m})$

Stem diameter data were taken through the use of Vernier caliper. In each treatment and every replication five plants were randomly selected and their stem diameter was calculated and then their mean was calculated for further statistical analysis.

\section{Days to $1^{\text {st }}$ flowering}


Days to $1^{\text {st }}$ flowering were recorded from plant sowing to emergence of $1^{\text {st }}$ flowering. And days were counted after emergence of more than 50 percent plants and then their average was calculated.

\section{Flower diameter (cm)}

Data of flower diameter were recorded with the help of Vernier caliper. Randomly five flowers were selected in each treatment and each replication and then their diameter was calculated. After that their average was noted for further analysis.

\section{Flower fresh weight (g)}

Data were taken by weighting fresh flower with the help of digital scale. Five randomly flowers were selected in every treatment and every replicates and their weight was noted and their mean was studied for further analysis.

\section{Flower dry weight (g)}

Randomly five plants were selected and then dried in oven. After that their weight was calculated by using electronic scale and then their average was noted.

\section{Total number of flowers plant ${ }^{-1}$}

Five plants were randomly selected in every treatment of the trial and then their flowers were counted. And then their average was calculated for further analysis.

\section{Flower shelf life (Day)}

For shelf life of marigold five flowers were selected and was kept at room temperature, their shelf life data were noted and then their average was calculated for further statistical analysis.

\section{Statistical procedure}

The data noted from the experiment was analyzed through analysis of variance method. Significant data were further analyzed through simple least significant differences (LSD) test. For all this calculation statistical software "Statistix 8.1" was used [14].

\section{Results and discussion}

The results obtained of different parameters are discussed as below

\section{Plant height (cm)}

Mean table (2) revealed that height of plant marigold was significantly affected by zinc and iron application amounts. However the interaction of these treatments was found non-significant. Maximum plant height of marigold $(49.04 \mathrm{~cm})$ was recorded on $0.4 \%$ of zinc application followed by $0.6 \%$ of zinc application $(47.86 \mathrm{~cm})$, while the smallest height of plant $(46.18 \mathrm{~cm})$ was observed in local.In case of iron application, the maximum plant height $(51.22 \mathrm{~cm})$ of marigold was noted on $0.3 \%$ application of iron while the smallest plant height (43.77 $\mathrm{cm})$ was recorded in control.

Zinc has a key role in the absorption of auxin [15]. Zinc application also has a main part in the activation of several enzymes, construction of tryptophan, structure of protein and also an originator of plant growth hormones due to which the plant height of the plant increased [16]. Our experiment results are similar with the result of [17] who noted that the use of zinc at the rate of $0.4 \%$ increased the plant height of the plants. Iron is an important structural and functional component of many enzymes. The applications of iron at the rate of $2 \%$ increased photosynthesis of the plant which result in improve growth [18].

\section{Table 2. Plant height (cm) of marigold as affected by application of zinc and iron levels}




\begin{tabular}{|c|c|c|c|c|}
\hline \multirow{2}{*}{ Zinc Levels (\%) } & \multicolumn{3}{|c|}{ Iron levels (\%) } & \multirow{2}{*}{ Mean } \\
\cline { 2 - 4 } & $\mathbf{0}$ & $\mathbf{0 . 3}$ & $\mathbf{0 . 6}$ & \\
\hline $\mathbf{0}$ & 42.12 & 46.62 & 49.80 & $\mathbf{4 6 . 1 8 c}$ \\
\hline $\mathbf{0 . 2}$ & 43.38 & 46.68 & 50.51 & $\mathbf{4 6 . 8 6 c}$ \\
\hline $\mathbf{0 . 4}$ & 44.92 & 47.22 & 51.44 & $\mathbf{4 9 . 0 4 a}$ \\
\hline 0.6 & 44.67 & 49.34 & 53.11 & $\mathbf{4 7 . 8 6 b}$ \\
\hline Mean & $\mathbf{4 3 . 7 7 c}$ & $\mathbf{5 1 . 2 2 a}$ & $\mathbf{4 7 . 4 7 b}$ & \\
\hline
\end{tabular}

LSD value at $5 \%$ probability levels for zinc:

\section{Number of branches plant ${ }^{-1}$}

Mean table (3) indicated that the foliar application of zinc and iron significantly affected the number of branches plant $^{-1}$, while the interaction of treatments was nonsignificant. The highest numbers of branches per plant (17.33) of marigold was recorded in those plots which were treated with $0.6 \%$ application of zinc which was followed by $0.4 \%$ of zinc application (16.56). However the minimum number of branches per plant (14.89) was recorded in control plots. In case of iron application, the highest number of branches per plant (18.58) was recorded on $0.6 \%$ application of iron as a foliar spray, while the minimum number of branches plant $^{-1}(13.83)$ was noted in control plots. Increase in number of branches plant ${ }^{-1}$ may be due to the reason that zinc is an important micronutrient for growth and development of plant. It has been reported that zinc is a part of numerous enzymes in the plant body. High concentration of zinc increased the rate of photosynthesis due to which increase occur in plant development [19]. Our result is similar to the result of [20]who noted that significant increase occur in number of branches per plant of marigold due to foliar application of $0.5 \%$ zinc. The deficiency of iron causes chlorosis in the plants. Iron also increased the rate of chlorophyll due to which the development of the plant increased [21]. Similar results was noted by [22]. Who stated that the foliar application of iron at the rate of $0.75 \%$ significantly increase the number of branches in chrysanthemum plant. In another study [23]concluded that the application of iron at the rate of $0.5 \%$ increased the number of branches of chrysanthemum.

Table 3. Number of branches plant ${ }^{-1}$ of marigold as affected by application of zinc and iron levels

\begin{tabular}{|c|c|c|c|c|}
\hline \multirow{2}{*}{ Zinc Levels (\%) } & \multicolumn{3}{|c|}{ Iron levels (\%) } & \multirow{2}{*}{ Mean } \\
\cline { 2 - 4 } & $\mathbf{0}$ & $\mathbf{0 . 3}$ & $\mathbf{0 . 6}$ & \\
\hline $\mathbf{0}$ & 12.00 & 15.67 & 17.00 & $\mathbf{1 4 . 8 9 d}$ \\
\hline $\mathbf{0 . 2}$ & 14.00 & 15.67 & 17.67 & $\mathbf{1 5 . 7 8 b c}$ \\
\hline $\mathbf{0 . 4}$ & 14.67 & 16.00 & 19.00 & $\mathbf{1 6 . 5 6 a b}$ \\
\hline $\mathbf{0 . 6}$ & 14.67 & 16.67 & 20.67 & $\mathbf{1 7 . 3 3 a}$ \\
\hline Mean & $\mathbf{1 3 . 8 3 c}$ & $\mathbf{1 6 . 0 0 b}$ & $\mathbf{1 8 . 5 8 a}$ & \\
\hline
\end{tabular}

LSD value at $5 \%$ probability levels for zinc: 1.01

LSD value for $5 \%$ probability levels for iron: $\quad 0.88$

\section{Stem diameter (cm)}

Mean table (4) indicated that stem diameter of marigold was significantly affected by foliar application of zinc and iron, while the interaction of the treatments was found non- significant. The highest stem diameter (1.12 $\mathrm{cm}$ ) of marigold was noted on $0.4 \%$ foliar application of zinc, whereas the minimum stem diameter (1.02) of marigold was recorded in control plot.Stem diameter of 
marigold was also significantly increased with the application of iron. The maximum stem diameter of marigold $(1.19 \mathrm{~cm})$ recorded on $0.3 \%$ application of iron as a foliar spray, while the minimum stem diameter $(0.94 \mathrm{~cm})$ was recorded on control. Zinc is an essential nutrient for the growth and production of plant [24]. It has been noted that zinc is important constituent of ribosome and is essential for their production. The addition of zinc to plants can increase the accumulation of amino acid in the plant tissues and also enhanced the formation of protein as a result of which plant growth increased [25]. Similar result was presented by [26] who reported that zinc application at the rate of $1 \%$ significantly improved the stem diameter of marigold. Iron is an important constituent of various proteinase, peptides, dehydrogenize and also enhance plant growth hormones which improve plant growth. All these hormones increased cell division, cell differentiation and cell multiplication due to which the rate of photosynthesis increased which results increased in stem diameter [27]. Similar result was noted by [28] who reported that the diameter of stem was improved with the application of zinc and iron. Shah et al. (2015) [20] also reported that the maximum stem diameter was noted on $0.5 \%$ iron sulphate application.

Table 4. Stem diameter (cm) of marigold as affected by application of zinc and iron levels

\begin{tabular}{|l|l|l|l|l|}
\hline \multirow{2}{*}{ Zinc Levels (\%) } & \multicolumn{2}{|l|}{ Iron levels (\%) } & \multirow{2}{*}{ Mean } \\
\cline { 2 - 5 } & $\mathbf{0}$ & $\mathbf{0 . 3}$ & $\mathbf{0 . 6}$ & \\
\hline $\mathbf{0}$ & 0.89 & 1.14 & 1.02 & $\mathbf{1 . 0 2 d}$ \\
\hline $\mathbf{0 . 2}$ & 0.94 & 1.18 & 1.07 & $\mathbf{1 . 0 6 c}$ \\
\hline $\mathbf{0 . 4}$ & 0.99 & 1.24 & 1.12 & $\mathbf{1 . 1 2 a}$ \\
\hline $\mathbf{0 . 6}$ & 0.94 & 1.21 & 1.10 & $\mathbf{1 . 0 8 b}$ \\
\hline Mean & $\mathbf{0 . 9 4}$ & $\mathbf{1 . 1 9 a}$ & $\mathbf{1 . 0 8 b}$ & \\
\hline
\end{tabular}

LSD value at $5 \%$ probability levels for zinc: $\quad 0.011$

LSD value for $5 \%$ probability levels for iron: $\quad 0.009$

\section{Days to flowering}

Mean table (5) revealed that days to flowering of marigold was significantly affected by foliar application of zinc and iron levels. However the treatments interaction was non-significant. The minimum days to flowering of marigold (16.67 days) was recorded on $0.6 \%$ foliar application of zinc which was statistically similar with $0.40 \%$ application of zinc (17.11 days). The maximum days to flowering (18.11 days) was recorded on control. In case of foliar application of iron, the minimum days to flowering of marigold (15.42 days) was observed on $0.6 \%$ application of iron as a foliar spray, whereas the maximum days to flowering (20.0 days) was recorded in control plots.
The foliar application of zinc enhanced the metabolic activities of the plant which increased cell enlargement and cell elongation due to which the rate of photosynthesis increased and plant produced early flowering [29]. Our result is related with the result of [30]. Who concluded that the foliar application of zinc at the rate of 0.6 $\%$ significantly affected days to flowering of gerbera.It has been reported that the root system of the plant increased with the application of iron as a result of which plant utilize more water and nutrients which increase plant growth and leads toward reproductive growth [31]. Besides this iron also activates many enzymes such as catalase, peroxidase etc. Iron is also an important factor of the synthesis of chlorophyll due to which the photosynthesis 
rate increased and also increased plant growth which leads plant to early flowering [32]. Our result is similar to the findings of [33] who reported that iron application significantly affected the days to flowering of China aster. [34] Revealed that early flowering was obtained on $0.2 \%$ application of iron sulphate.

Table 5. Days to flowering of marigold as affected by application of zinc and iron levels

\begin{tabular}{|c|c|c|c|c|}
\hline \multirow{2}{*}{ Zinc Levels (\%) } & \multicolumn{3}{|c|}{ Iron levels (\%) } & \multirow{2}{*}{ Mean } \\
\cline { 2 - 4 } & $\mathbf{0}$ & $\mathbf{0 . 3}$ & $\mathbf{0 . 6}$ & $\mathbf{1 8 . 1 1 a}$ \\
\hline $\mathbf{0}$ & 20.67 & 17.33 & 16.33 & $\mathbf{1 7 . 6 7 b}$ \\
\hline $\mathbf{0 . 2}$ & 20.33 & 17.00 & 15.67 & $\mathbf{1 7 . 1 1 c}$ \\
\hline $\mathbf{0 . 4}$ & 19.67 & 16.33 & 15.33 & $\mathbf{1 6 . 6 7 d}$ \\
\hline 0.6 & 19.33 & 16.33 & 14.33 & \\
\hline Mean & $\mathbf{2 0 . 0 0 a}$ & $\mathbf{1 6 . 7 5 b}$ & $\mathbf{1 5 . 4 2 c}$ & \\
\hline
\end{tabular}

LSD value at $5 \%$ probability levels for zinc:

0.55

LSD value for $5 \%$ probability levels for iron: $\quad 0.48$

\section{Number of flowers plant ${ }^{-1}$}

Mean table (6) revealed that the foliar application of zinc and iron significantly affected the numbers of flowers plant ${ }^{-1}$, whereas the interaction of these treatments was found-non-significant. The maximum numbers of flowers plant ${ }^{-1}$ (10.11) of marigold was observed in those plots which were treated with $0.6 \%$ application of zinc which was followed by $0.4 \%$ application of zinc (9.67), whereas the minimum numbers of flowers plant ${ }^{-1}(8.56)$ was observed in control. In case of iron application as a foliar spray, the maximum numbers of flowers plant $^{-1}(10.79)$ was observed in plots which were treated with $0.6 \%$ foliar application of iron, while the minimum flowers plant $^{-1}$ (7.79) was recorded in control plots.
The increased in number of flowers plant ${ }^{1}$ maybe due to the useful and essential character of zinc in improving the translocation of carbohydrates, water, amino acid and mineral from source to sink particularly on flower as a result of which the number of flowers increased [7]. The similar result was also noted by [6] in African marigold at $0.75 \%$ zinc sulphate. There is a direct effect of iron on the synthesis of chlorophyll as a result of which the photosynthesis rate increased and produced more food, due to which the flower numbers plant ${ }^{-1}$ was increased [13]. Our finding are same with the finding of [23] who concluded that the application of iron the number of flowers plant ${ }^{-1}$ increased in French marigold.

Table 6. Number of flowers plant ${ }^{-1}$ of marigold as affected by application of zinc and iron levels

\begin{tabular}{|c|c|c|c|c|}
\hline \multirow{2}{*}{ Zinc Levels (\%) } & \multicolumn{3}{|c|}{ Iron levels (\%) } & \multirow{2}{*}{ Mean } \\
\cline { 2 - 4 } & $\mathbf{0}$ & $\mathbf{0 . 3}$ & $\mathbf{0 . 6}$ & $\mathbf{8 . 5 6 c}$ \\
\hline $\mathbf{0}$ & 6.67 & 9.33 & 9.67 & $\mathbf{9 . 3 3 b}$ \\
\hline $\mathbf{0 . 2}$ & 7.33 & 9.83 & 10.83 & $\mathbf{9 . 6 7 a b}$ \\
\hline $\mathbf{0 . 4}$ & 8.50 & 9.50 & 11.00 & $\mathbf{1 0 . 1 1 a}$ \\
\hline Mean & 8.67 & 10.00 & $\mathbf{1 0 . 7 9 a}$ & \\
\hline
\end{tabular}

LSD value at $5 \%$ probability levels for zinc:

LSD value for $5 \%$ probability levels for iron:

0.48

Flower diameter (cm) 
Mean table (7) shows that the flower diameter of marigold was significantly affected by the foliar application of zinc, iron and their interaction. The maximum flower diameter $(9.10 \mathrm{~cm})$ of marigold was observed on $0.6 \%$ application of zinc. However the minimum flower diameter $(8.28 \mathrm{~cm})$ was recorded on control. The maximum flower diameter $(9.48 \mathrm{~cm})$ of marigold was recorded on $0.6 \%$ of foliar application of iron, whereas the minimum flower diameter $(7.74 \mathrm{~cm})$ was noted in control plot.In case of interaction the maximum flower diameter $(9.80 \mathrm{~cm})$ was recorded on $0.6 \%$ zinc application and $0.6 \%$ application of iron, while the minimum flower diameter $(07.0 \mathrm{~cm})$ was recorded on control.

Studies showed that zinc is an important micro nutrient for plant growth and development [9]. Several enzymes are activated with the application of zinc such as tryptophan, dehydrogenase etc. Zinc is also an important factor of the formation of chlorophyll and several other physiological due to which the flower diameter increased [35]. [36] Concluded that zinc application at the rate of $0.4 \%$ gave maximum flower diameter of lilium. Iron is related with the formation of chlorophyll. Iron also act as a catalyst in many reactions. It is also important for photosynthesis and respiration [10]. The same result was noted by [37]. Our results are confirmed with the results of [34] who revealed that the application of $0.4 \%$ iron increased the flower diameter of African marigold.

Table 7. Flower diameter $(\mathrm{cm})$ of marigold as affected by application of zinc and iron levels

\begin{tabular}{|l|l|l|l|l|}
\hline \multirow{2}{*}{ Zinc Levels (\%) } & \multicolumn{3}{|l|}{ Iron levels (\%) } & \multirow{2}{*}{ Mean } \\
\cline { 2 - 5 } & $\mathbf{0}$ & $\mathbf{0 . 3}$ & $\mathbf{0 . 6}$ & \\
\hline $\mathbf{0}$ & 7.00 & 8.53 & 9.30 & $\mathbf{8 . 2 8} \mathbf{~ d}$ \\
\hline $\mathbf{0 . 2}$ & 7.50 & 8.77 & 9.37 & $\mathbf{8 . 5 4} \mathbf{c}$ \\
\hline $\mathbf{0 . 4}$ & 8.13 & 9.00 & 9.47 & $\mathbf{8 . 8 7} \mathbf{b}$ \\
\hline $\mathbf{0 . 6}$ & 8.33 & 9.17 & 9.80 & $\mathbf{9 . 1 0} \mathbf{a}$ \\
\hline Mean & $\mathbf{7 . 7 4} \mathbf{c}$ & $\mathbf{8 . 8 7} \mathbf{b}$ & $\mathbf{9 . 4 8} \mathbf{a}$ & \\
\hline
\end{tabular}

LSD value at $5 \%$ probability levels for zinc: $\quad 0.10$

LSD value for $5 \%$ probability levels for iron: $\quad 0.09$

\section{Fresh weight of flower (g)}

Mean table (8)shows that fresh flower weight of marigold was significantly affected by foliar application of zinc and iron, the interaction of the treatment was found nonsignificant. The maximum fresh weight of flower $(17.51 \mathrm{~g})$ was observed in those plots which were treated with $0.6 \%$ application of zinc as a foliar spray followed by $0.4 \%$ zinc application $(16.0 \mathrm{~g})$. The minimum fresh weight $(14.18 \mathrm{~g})$ of flower was recorded in control plots. In case of iron application, the maximum fresh weight of flower $(19.36 \mathrm{~g})$ was observed on $0.6 \%$ application of iron as foliar spray, while the minimum fresh weight of flower $(12.59 \mathrm{~g})$ was recorded in control plots.

Bharracharjee [38] revealed that the foliar application of zinc plays a vital role in plant growth. Zinc is involves in photosynthesis process, metabolism of indole acidic acid and in the formation of protein and auxin. The fresh flower weight was maximum due to cell division, growth and respiration [29]. The similar results were noted by [12] who concluded that the fresh flower weight of gladiolus increased with foliar zinc application. [20]Noted that the $0.5 \%$ application of zinc sulphate gave maximum fresh weight of marigold. Iron plays as a catalyst role in several chemical reactions 
and thus enhanced these reactions [39]. Our result is similar to the results of [40] who determined that the foliar application of iron significantly improved the fresh flower weight of tuberose. Our results are similar with the result of [34] who concluded that the iron sulphate application at the rate of $0.4 \%$ increases the fresh weight of African marigold.

Table 8. Fresh flower weight of marigold (g) as affected by application of zinc and iron levels

\begin{tabular}{|c|c|c|c|c|}
\hline \multirow{2}{*}{ Zinc Levels (\%) } & \multicolumn{3}{|c|}{ Iron levels (\%) } & \multirow{2}{*}{ Mean } \\
\cline { 2 - 4 } & $\mathbf{0}$ & $\mathbf{0 . 3}$ & $\mathbf{0 . 6}$ & $\mathbf{1 4 . 1 8 c}$ \\
\hline $\mathbf{0}$ & 11.16 & 14.81 & 16.56 & $\mathbf{1 5 . 5 3 b}$ \\
\hline $\mathbf{0 . 2}$ & 12.46 & 14.91 & 19.22 & $\mathbf{1 6 . 0 0 b}$ \\
\hline $\mathbf{0 . 4}$ & 12.83 & 15.39 & 19.77 & $\mathbf{1 7 . 5 1 a}$ \\
\hline Mean & 13.92 & 16.71 & 21.90 & \\
\hline
\end{tabular}

LSD value at $5 \%$ probability levels for zinc: 0.18

LSD value for $5 \%$ probability levels for iron: $\quad 0.15$

\section{Dry weight of flower (g)}

Mean table (9) shows that the dry weight of flower was significantly affected by the foliar application of zinc, iron and their interaction. The maximum dry weight of flowers $(3.06 \mathrm{~g})$ of marigold was noted in those plots which were treated with $0.6 \%$ foliar application of zinc. The minimum dry weight of flower $(2.49 \mathrm{~g})$ was recorded on control. In case of iron application, the maximum dry weight of flower $(3.40 \mathrm{~g})$ was recorded on $0.6 \%$ application of iron, whereas the minimum dry weight of flower $(2.02 \mathrm{~g})$ was observed in control plots. In terms of interaction between the zinc and iron, the maximum dry weight of flower $(3.55 \mathrm{~g})$ was recorded on $0.6 \%$ zinc and $0.6 \%$ iron, while the minimum dry weight of flowers (1.53 g) was observed in control.

A significant variation was observed on dry flower weight of marigold with the foliar Table 9. Dry weight of marigold flower (g) as affected by application of zinc and iron levels

\begin{tabular}{|c|c|c|c|c|}
\hline \multirow{2}{*}{ Zinc Levels (\%) } & \multicolumn{3}{|c|}{ Iron levels (\%) } & \multirow{2}{*}{ Mean } \\
\cline { 2 - 4 } & $\mathbf{0}$ & $\mathbf{0 . 3}$ & $\mathbf{0 . 6}$ & 2.49d \\
\hline $\mathbf{0}$ & 1.53 & 2.68 & 3.28 & $\mathbf{2 . 6 9 c}$ \\
\hline $\mathbf{0 . 2}$ & 1.91 & 2.85 & 3.32 & $\mathbf{2 . 8 6 b}$ \\
\hline $\mathbf{0 . 4}$ & 2.15 & 2.98 & 3.46 & 3.06a \\
\hline Mean & 2.51 & 3.13 & 3.55 & \\
\hline
\end{tabular}

LSD value at $5 \%$ probability levels for zinc:

LSD value for $5 \%$ probability levels for iron:

0.03

0.04 application of zinc. It has been reported that the foliar application of zinc relived chlorosis in the leaves of the plant and produced green and healthy plants. Zinc is also a significant constituent of chlorophyll by which the photosynthesis of the plant increases which resulting maximum flower weight [41]. The same result was noted by [42] who reported that the dry weight of chrysanthemum was increased with zinc application. They noted that the $0.6 \%$ zinc sulphate produce maximum dry weight of flowers. Iron act as a catalyst in several chemical reactions and plays a role in the synthesis of chlorophyll and other physiological activities due to which flower weight and yield may be enhanced [12]. The similar result was noted by [43] who reported that the dry mass of African marigold improved with the application of iron and zinc at the rate of 0.5 $\%$ and $0.75 \%$ respectively. 


\section{Shelf life (Day)}

Mean table (10) revealed that the foliar application of zinc and iron significantly affected the shelf life of marigold flowers, whereas their interaction was non-significant. The maximum shelf life of marigold flower (5.22 days) was recorded on $0.6 \%$ of zinc application, followed by $0.4 \%$ application of zinc (4.67 days). The minimum shelf life of marigold flower (4.44 days) was observed on control.In case of iron application the maximum shelf life of marigold flower (5.67 days) was recorded in those plots which were treated with $0.6 \%$ iron, whereas the minimum shelf life of marigold flower (3.83 days) was recorded on control.

Application of zinc plays an important role to produce good quality flowers and increased the shelf life of flower [25]. [44] Observed that the application of zinc significantly influence the shelf life of gladiolus. [45] Stated that the proper application of zinc significantly enlarged the shelf life of orchid.
Our result is similar to the conclusion of [46] who reported that the shelf life of tuberose improved with the application of zinc. Iron also increased the storage of carbohydrates through the increased in the rate of photosynthesis [47]. Iron also plays an important role in the formation of plant hormones and chlorophyll contents and as a result of this the shelf life of the flower increased [48]. Our results is similar to the result of [6] who stated that the shelf life of African marigold improved with the application of iron. Iron is also related with the establishment of chlorophyll. Iron has also a key character in the activation of several enzymes [12]. The studies showed that the application of iron and zinc play a role in the physiological growth of the flowers and reduced the amount of ethylene and abscisic acid and as a result of which the shelf life and visual attraction of the flowers increased [13].

Table 10. Shelf life (Day) of marigold flower as affected by application of zinc and iron levels

\begin{tabular}{|l|l|l|l|l|}
\hline \multirow{2}{*}{ Zinc Levels (\%) } & \multicolumn{3}{|l|}{ Iron levels (\%) } & \multirow{2}{*}{ Mean } \\
\cline { 2 - 5 } & $\mathbf{0}$ & $\mathbf{0 . 3}$ & $\mathbf{0 . 6}$ & \\
\hline $\mathbf{0}$ & 3.33 & 4.67 & 5.33 & $\mathbf{4 . 4 4 b}$ \\
\hline $\mathbf{0 . 2}$ & 4.00 & 4.33 & 5.33 & $\mathbf{4 . 5 6 b}$ \\
\hline $\mathbf{0 . 4}$ & 3.67 & 4.67 & 5.67 & $\mathbf{4 . 6 7 b}$ \\
\hline $\mathbf{0 . 6}$ & 4.33 & 5.00 & 6.33 & $\mathbf{5 . 2 2 a}$ \\
\hline Mean & $\mathbf{3 . 8 3 c}$ & $\mathbf{4 . 6 7 b}$ & $\mathbf{5 . 6 7}$ & \\
\hline \\
LSD value at 5 \% probability levels for zinc: \\
LSD value for 5\% probability levels for iron: 0.44 &
\end{tabular}

\section{Conclusion}

On the basis of above results the following conclusions can be made:The application of zinc at the rate of $0.6 \%$ gave maximum number of branches plant $^{-1}$, number of flowers plant $^{-1}$, flower diameter, fresh flower weight, dry flower weight, shelf life and minimum days to flowering. The application of zinc at the rate of $0.4 \%$ gave maximum plant height and stem diameter. In case of iron application maximum number of branches plant ${ }^{-1}$, number of flowers plant ${ }^{-1}$, flower diameter, fresh flower weight, dry flower weight, shelf life and minimum days to flowering were recorded on $0.6 \%$ iron. The application of iron at the rate of $0.3 \%$ gave maximum plant height and stem diameter.

\section{Authors' contributions}

Conceived and designed the experiments: $G$ Nabi\& M N Khan, Performed the experiments: A Hussain, Analyzed the data: 
W Muhammad, Contributed materials/ analysis/ tools: Y Ali, W Khan, S Zeb \& M Hilal, Wrote the paper: M Ilyas.

\section{References}

1. Achla K \& Ram L (2011). Influence of Integrated Nutrient Management on the Yield attributes and uptake of nutrients by Tagetes erecta (Marigold-A. Yellow) in semi-arid eastern plain zone of Rajasthan. Dep Soil Sci Agric Chem Agric Res Station, Durgapura, Jaipur, India pp 1-11.

2. Sunitha $H M(2006)$. Effect of plant population, nutrition, pinching and growth regulators on plant growth, seed yield and quality of African marigold. M. Sc. (Hort) Thesis, Univ Agric Sci, Dharward, India.

3. Bunghez IR \& Ior RM (2011).Complex spectral characterization of active principles from marigold. $J$ Sci and Arts 1(1): 59-64.

4. Ashoori M, Lolaei A, Ershadi A, Kolhar M \& Rasoli A (2013). Effects of N, Fe and $\mathrm{Zn}$ Nutrition on Vegetative and Reproductive Growth and Fruit Quality of Grapevine. J Ornam Hoti Plants 3(1): 49-58.

5. Ardalani H, Hadipanah A \& Pourrezvani SM (2014). Foliar Application Gibberellic acid and Ethanol on flower yield and Phenolic compositions in marigold. Elect J Bio 10(3): 73-78.

6. Balakrishnan V, Jawaharlal M, Kumar TS \& Ganga M(2007). Response of micronutrients on flowering, yield and xanthophyll content in African marigold. J Orna Hort 10(3): 153-156.

7. Gurav SB, Katwate M, Singh BR, Sabale RN, Kakade DS \& Dhane AV (2004). Effect of nutritional levels on yield and quality of gerbera. J Orna Hort 7(3-4): 226-229.

8. Sarwar M, Jilani G, Rafique E, Akhtar ME \& Chaudhry AN (2012). Impact of integrated nutrient management on yield and nutrient uptake by maize under rainfed conditions. Pak $J$ of Nutrition 11(3): 27-33.

9. Nasiri Y, Zehtab SS, Nasrullahzadeh S, Najafi N \& Ghassemi K (2010). Effect of foliar application of micronutrients (Fe and $\mathrm{Zn}$ ) on flower yield and essential oil of chamomile. $J$ Med Plants Res 4(17): 1733-1737.

10. George P \& Maneul J (2013). Low cost tissue culture technology for the regeneration of some economically important plants for developing countries. Inter J Agric Environ and Biotech 6: 703-711.

11. Singh JP, Kumar K \& Katiyar PN (2012). Effect of zinc, iron and copper on yield parameters of gladiolus. Hort Flora Res Spect 1(1): 64-68.

12. Sharma J, Gupta AK, Kumar CK \& Gautam RKS (2013). Influence of zinc, calcium and boron on vegetative and flowering parameters of gladiolus cv. Aldebran. The Bioscan8(4): 1153- 1158.

13. Vijayakumar N (2009). Effect of growing media and nutrients on growth, yield and quality of Asparagus sprengeri L. Kunth. M.Sc. (Ag.) Hort. Thesis, Annamalai University, Annamalainagar, T.N. (INDIA).

14. Steel RGD \& Torrie (1980). Principles and Procedures of Statistics. 2nd Edition, New York, McGraw-Hill, pp 172-177.

15. Marschner H (1995). Mineral nutrition of higher plants. Academic Press. $2^{\text {nd }}$ Ed. Harcourt Brace and company Publishers.

16. Brown PH, ChakmakI \& Zhang Q (1993). Form and function of zinc in plants. J Maharashtra Agric Uni 11(2): 199-201.

17. Broadley MR, White PJ, Hammond JP, Zelko I \&LuxA (2007). Zinc in plants. New Phytologist 173(2): 677-702.

18. Baloch OB, Chacar OI \& Tareen MN (2008). Effect of foliar application of macro and micro nutrients on production 
of green chilies. J Agri Tech 4(2): 177 184.

19. Gao XP, Zou EQ, Fan XY, Zhang FS \& Land EH (2006). From flooded to aerobic conditions in rice cultivation: Consequences for zinc uptake. $J$ Plant Soil 280(4): 41-47.

20. Shah ST, Ullah S, Khan N, Sajid M, Rab A, Ul-Amin N, Iqbal A, Iqbal M, Ul-Haq S, Rahman S, Shah FA \& Rizwan $\mathrm{S}(2015)$. Effect of zinc as a foliar spray on growth and flower production of marigold. Academia J Agri Res 4(3): 140-144.

21. Pestana M, David M, de Varennes A, Abadi JA \& Faria EA (2001). Response of "New hall" orange tree stoir on deficiency in hydroponics: Efect on leaf chlorophyll, photosynthetic and root ferric chelate reductase activity. $J$ Plant Nutri 24(3): 1609-1620.

22. Khalaj MA, Edrisi A \& Amiri M (2012). Effect of nitrogen, zinc and plant spacing on nutrients uptake, yield and growth of tuberose. J Ornam Horti Plants 2(1): 4554.

23. Karuppaiah $\mathrm{P}(2006)$. Effect of spacing and nutrient levels on flower yield, carotenoid content, nutrient uptake and residual soil fertility in French marigold. Inter J AgricSci 2(2): 375-376.

24. Singh AK, Hembron R, Singh J, Sisodia A \& Pal AK (2015).Effect of iron and zinc on growth and post-harvest life in lilium cv. Tresor. Envirn and Eco 33(2): 625-628.

25. Patel H, Henaxi K, Bhatt B, Patel GD, Chawlal SL \& Tulsi G (2016). Effect of foliar application of micronutrients on Growth and flowering of rose cv. Top secret under Polyhouse condition. The Bioscan 11(1): 603-606.

26. Moustakas NK, Akoumianaki AI \& Barouchas PE (2011). The effects of cadmium and zinc interactions on the concentration of cadmium and zinc in pot marigold. Australian J of Crop Sci 5(3): 277-282.

27. Deshmukh MR \& Wavhal KN (1998). Effect of iron on growth and flowering of aster. J Maharashtra AgricUni23(2): 99101.

28. Kumar P, Singh D\&Kumar S(2010). Effect of pre-harvest micronutrient foliar spray on growth, flowering and seed production in marigold. ProgAgric 10(1): 182-183.

29. Khosa SS, Younis A, Rayit A, Yasmeen $S$ \&Riaz A(2011). Effect of foliar application of macro and micro nutrients on growth and flowering of Gerbera. American-Eurasian J Agric \& Environ Sci 11(5): 736-757.

30. Bashir MA, Waqas A, Ahmad KS, Shafi J, Shehzad MA, Sarwar MA, Ghani I \&Iqbal M(2013). Efficacy of foliar application of micro nutrients on growth and flowering of Gerbera. Universal $J$ Agric Res 1(4): 145-149.

31. Chandanshive PD (2011). Effect of micronutrients on growth, flowering and cut flower yield of rose (Rosa hybrid Linn.) cv. FIRST RED under protected condition. M.Sc. (Hort.) Thesis. Junagadh Agricultural University, Junagadh, Gujarat (INDIA).

32. Fakhraie ML (2012). Application of micronutrients FeSO4 and $\mathrm{ZnSO} 4$ on the growth and development of gladiolus variety Oscar. Inter J Agric \& Crop Sci 4(11): 718-720.

33. Kakade DK, Rajput SG \& Joshi $\mathrm{KI}(2009)$. Effect of foliar application of 'Fe' and ' $\mathrm{Zn}$ ' on growth, flowering and yield of China aster. Asian J Hort 4(1): 138-140.

34. Kumar R, Kumar A \& Kumar A (2018). Effect of nutrients on growth, flowering and yield of African marigold. cv. Pusa Narangi Gainda. Inter J Curr Microbiol Appl Sci 7(6): 205-209. 
35. Tariq M, Saeed S, Hassan M, Imran A, Jilani K, Ghulam M \& Abbasi NA (2013). Zinc augments the growth and floral attributes of gladiolus, and alleviates oxidative stress in cut flowers. Sci Hort 164: 124-129.

36. Singh AK, Asmita A, Sisodia A \& Hembrom R (2015). Effect of foliar application of zinc and copper on leaf nutrient content, growth and flowering in glodiolus. Indian J Agri Sci 85(7): 95-99.

37. Patel TD, Viradia DRR, Tejashwini CR, Patel HV \& Patel UR (2017). Studies on effect of foliar application of micronutrient ( $\mathrm{Fe} \& \mathrm{Zn}$ ) on growth, flowering quality and yield of tuberose. CV. Prajwal. Inter J Chem Studies 5(6): 93-97.

38. Bhattacharjee SK (1993). Response of micronutrients spray on growth and flowering of rose cv. Raktagandha. Indian Rose Annual 11: 108-113.

39. Memon SA, Abdul RA, Muhammad AB \& Mahmooda B (2013). Effect of zinc sulphate and iron sulphate on the growth and flower production of gladiolus. $J$ Agric Tech 9(3): 1621-1630.

40. Eidyan B, Hadavi E \& Moalemi N (2014). Pre-harvest foliar application of iron sulfate and citric acid combined with urea fertigation affects growth and vase life of tuberose. Por-Par Horti Environ Biotech 55(4): 9-13.

41. Nag MR \&Biswas J (2002). Studies on effect of boron on vegetative and reproductive growth in tuberose cv.single. Orissa J Hort 30(2): 39-42.
42. Naveenkumar P, Misra BL, Ganga M, Dhiman SR \& Lalitha K (2009). Effect of micronutrients sprays on growth and flowering of chrysanthemum. Indian $J$ Hort Sci 76(6): 426-428.

43. Jat RN, Khandelwal SK \& Gupta KN (2007). Effect of foliar application of urea, iron and zinc sulphate on growth and flowering parameters in African marigold. J Orna Hort 10(4): 271-273.

44. Chopde N, Nehare N, Bhande MH \& Lokhande S (2016). Growth, yield and quality of gladiolus as influenced by micronutrients. J Soil and Crops 26(1): 131-133.

45. Ganga M, Padmdevi K, Jegadeeswari V \& Jawaharlal M (2009). Performance of Dendrobiumcv. Sonia 17 as influenced by micronutrients. $J$ Ornamental Hort 12(1): 39-43.

46. Tayade M, Badge S \& Nikam B (2018). Foliar application of zinc and iron as influenced on flowering and quality parameters of Tuberose. Inter $J$ Curr Micro Bio Appl Sci 7(1): 2239-2243.

47. Ganesh S, Sundaram SK \& Kannan M (2013). Studies on effect of plant growth regulators and micronutrients on growth, floral characters and yield of tuberose. cv. 'Prajwal'. Asian J Hort 8(2): 696700.

48. Fahad S, Ahmad M, Akbar AM \& Hussain S (2014). The Effect of Micronutrients (B, Zn and Fe) Foliar Application on the Growth, Flowering and Corm Production of Gladiolus. $J$ Agric Sci Tech 16: 1671-1682. 